\title{
The Representation of the Evenkis and the Evenki Culture by a Local Community Museum
}

\author{
SVETLANA HUUSKO
}

\begin{abstract}
This article focuses on the representations of Evenkis and their culture in a local museum in Nizhneangarsk, Russia. The article uses the elements of critical discourse analysis to highlight the interplay between the real, imaginary, and ideological. The article explores how museum representations of the Evenkis and the Evenki culture create the ideological construction of the nature of the Evenkis and reproduce ethnic hierarchies in the region. The article examines the discursive strategies, rhetoric and meaning of texts, and the events presented by the museum's exhibitions. The article shows how the museum creates the nature of the Evenkis as external others, primitive folk, in contrast to the Evenkis as internal others, citizens of the contemporary Russian society, in its attempts to shape local identities.
\end{abstract}

Keywords: Evenki, identity, modernity, museums, representation

W hen visiting the Severobaikal'skii Museum of Local History in Nizhneangarsk in 2012 and later in 2016, I had a sense of the unquestionable reality of the community through the representation of its place in the history of Russia. A visitor can read the names of its exhibitions and halls_- "Exploration of Northern Transbaikalia," "History of the settlements of Severobaikal'skii district," "Socialist way of life," "Baikal-Amur Mainline Railway," "Fish factory-the glory of Baikal, the pride of the district," "Hall of Combat and Military Glory," and "The Aborigines of Severobaikal'skii district-the Evenkis." By this choice of exhibitions and their order, the museum explicitly connects the region historically and politically to Russia. As the museum's curator stated: "We have recently changed the exhibitions' order. We organized them more logically-we start our guided tour with 
the establishment of the first winter hut and fortress by the Russian Cossacks and finish it with the indigenous people of Severobaikalia." I argue that by doing so, the museum effectively positions the Evenki indigenous population of the region as an object discovered and civilized through the establishment of first Russian settlements, Soviet lifestyle, and industrialization; it consistently attempts to frame indigenous populations and their identities through art, history and a constructed national storyline.

In this article, I examine the role of the museum's representations of the Evenkis in relation to the museum's attempts to shape local identities. I begin by contextualizing Evenki history to show how the present-day local and museum representations of the Evenkis are the outcome of a long process, including colonization, state objectives, ideology, and policies toward indigenous populations and expansion of tsarist Russia, followed by the construction and strengthening of the Soviet and later-Russian-national identity. Next, I outline the methodology used and position my analysis within the critical discourse. I then discuss how the museum reinforces the dominant vocabularies and discourses and develops a storyline of the Evenkis and their history which exists only within the state; in other words, it has been written for the Evenkis and local people based solely on state ideology. I show how this story, created by the museum, not only deprives the Evenkis of their history and culture but also provides roots for local stereotypes and choices for the young Evenkis. Based on Philip Deloria's (1998) differentiation between the "external" and "internal" others, I examine how the museum's narrative effectively internalizes the "pre-Soviet" Evenkis as "exterior primitive other" into the "internal other," or the Evenkis as Soviet/Russian citizens.

\section{The Evenkis and the Weight of History: Objects of Policies and Continuous Violations}

The Evenkis are officially recognized in Russia as one of "the indigenous small-numbered peoples of the North, Siberia and the Far East."1 One of the Tungus-speaking groups in Northern Transbaikalia, by the 17th century Evenkis were nomadic and transhumant hunters, fishers, and pastoralists, herding reindeer, horse, and cattle (Shubin 2001; Ulturgasheva 2012). Their homelands spanned across North Asia from the Putorana mountains at the base of the Taimyr Peninsula in the North, to Mongolia and Manchuria in China in the South, and 
from the Yenisei River in the West, to the Okhotsk Sea in the East (Lee 2013; Ulturgasheva 2012). The Evenkis are often referred to as the northern and the southern according to their mode of subsistence (Lee 2013). The northern Evenkis were engaged in hunting and fishing, maintaining domesticated reindeer for transportation, or larger-scale reindeer breeding (Fondahl 1998; Vasilevich and Smolyak 1964). The southern Evenkis, or murchens, were mostly transhumant, organized into patriarchal clans, shifting their camps with herds of cattle and horses from winter to summer pastures (Shubin 2001; Vasilevich and Smolyak 1964).

My own fieldwork was conducted in contemporary Severobaikal'skii district in Buriatiia, which is home to the northern Evenkis, or orochons. Prior to the first contacts with the Russian Empire, they were organized into patriarchal clans (Vasilevich and Smolyak 1964). A typical Evenki clan was patrilineal-a collective of blood relatives who had a common ancestry in the male line-and patrilocal. For the past four hundred years, Russian and Soviet authorities have sought to incorporate Evenkis into the wider Russian/Soviet state politically, economically, and culturally (Bartels and Bartels 1995).

The Evenkis first came into contact with Russians in the mid-seventeenth century, when Cossacks reached Lake Baikal in a quest for new lands and furs. The Cossacks were the backbone of Russian expansion in Siberia. The Russian Empire recruited them to make alliances with Siberian tribes, including the Evenkis, and collect an obligatory annual fur tribute called yasak (Bisher 2006). Northern Transbaikalia was home to the most valuable of the sable species, the dark Barguzin sable that ensured the continued importance of Siberia in the world fur market. By the end of the seventeenth century, in pursuit of the yasak tribute of furs and control over trade, Russian settlers had established the network of the fortresses, trading posts, and winter huts; their presence was followed by the outbreaks of smallpox, syphilis, and influenza in isolated clans (Fondahl 1998). Those Evenkis who lived near gold mines and accessible sable hunting grounds suffered total land dispossession and were forced to relocate farther north or look for paid jobs in other clans or in the Russian settlements. The situation consequently led to a significantly decreased population of Evenkis and the merging of isolated clans (Bisher 2006; Fondahl 1998; Landers 2011).

In 1822, Mikhail Speransky, a close adviser to the Russian tsar Alexander I, advanced a 'Statute on the Administration of Aliens in Siberia' to protect the further provision of fur in the face of sable overhunting and the danger of its extinction. This law ensured that settled 
"aliens" (native people), inorodtsy, had the same rights as Russians. For the "wandering" (brodiachie) natives (including nomadic Evenki reindeer herders), a statute provided allotments of land for them to subsist on. These allotments guaranteed rights of occupancy, usage, and administration of state-owned land. Other groups had to ask permission to lease those allotted territories. The allotments were distributed to native clans established by the same statute, rather than to the already-existing clans, while some of the existing clans were merged. For administrative purposes, the state identified the "elders" who were elected under the Russian supervision, to ensure that those elected were the most reliable and responsive to state needs (Fondahl 1998). Consequently, by the beginning of the eighteenth century, the Evenkis began forging strong commercial ties with both Russians and Buriat through a specialized exchange and become active participants in the Siberian fur trade. Eventually, the land dispossessions and commercial pursuits eroded the traditional subsistence economy and unsettled social institutions like the clan system even further (Vasilevich and Smolyak 1964).

Ultimately, it was the Bolshevik Revolution of 1917 that brought significant changes to the Evenki homelands and elsewhere in North Asia. Central Soviet ideologies were largely based on the Marxist theory of historical progress. One of the most important implications of this was that it purported the progressive nature of social development-from primitive communism (which members are described as generic, tribal beings, and herd animals), to slaveholding or the ancient mode, feudal mode, capitalist or bourgeois mode, to communist systems (Gandy 2012). According to the official Soviet view, the Siberian indigenous populations were culturally, socially, and economically primitive (Bashkuev 2013; Kozlov et al. 2007; Slezkine 1994). It was crucial to overcome such primitiveness and lift the Evenkis and their indigenous neighbors from timelessness and being "traditional" and bring them into history, or Marx's historical scale so that they would develop (Grant 1993). Such a passage from "tradition" to "modernity" required "modernization and industrialization within the Marxist-Leninist norms of social, economic, and political behavior" (Bartels and Bartels 1995: 5).

In the late 1920s, the Soviet state commenced a campaign of collectivization on the Evenki economy, with the goal of turning these nomadic people into sedentary, "civilized" Soviet citizens. Collectivization thus proceeded with the settlement and relocation of many Evenkis as well as the mass confiscation of their reindeer (Fondahl 1998; Shubin 2001). The Soviet state viewed the clan system as a form of exploitation of man by man, with an ideology of kinship supported both by the 
tsarist Russian system of indirect rule and by the clans' leaders and their ideologues-shamans. The creation of the new communist community and ideology required the destruction of the kinship ideology and the abolition of the power held by shamans (Ssorin-Chaikov 2001). Accordingly, the state considered shamans and wealthy reindeer herders as the main obstacles to the collectivization of indigenous areas in Siberia. One of the forms of resistance to collectivization was the mass killing of domestic animals like reindeer, horses, and cattle (Leete 2005; Shubin 2001). In some cases, these killings were made in the ceremonial form of sacrifice. Leete (2005) writes that the purpose of these mass sacrifices was not only a sabotage of collectivization but also a plea for help from the ancestors.

Shamanism was also considered "primitive and savage" in its character of expression (Hamayon 2002). The Soviet state considered shamans to be charlatans that exploited Siberian peoples and encouraged them to resist economic, medical, and educational reforms (Leete 2005). Consequently, shamans were prohibited from practicing healing, perform religious rituals, and receive payments for their activities; they were also divested of voting rights and taxed for "unearned wealth" (Ssorin-Chaikov 2001: 11). In the 1930s, many of the shamans faced radical repressions. By the 1940s, almost all Evenki shamans had been purged, and religious rites and ceremonies prohibited (Fondahl 1998; Leete 2005; Ssorin-Chaikov 2001).

Soviet efforts to harness the rich natural resources of Siberia for use in the national economy weakened the Evenkis' control of their homelands. Such efforts also brought growing numbers of newcomers to the Evenki land. Between the 1930s and the 1980s, Russians, Ukrainians, Baltic peoples, along with members of other ethnicities poured into Siberia following the state-sponsored industrialization of the area. The population of the Severobaikal'skii district rocketed from 2,644 in 1926 to 40,213 in 1989 (USSR Census 1926, 1989). By the 2010 Russian Census, the Evenkis constituted only 5 percent (226) of the 5,046 people in Nizhneangarsk, whereas Russians made up 87 percent $(4,364)$, Buriats 3 percent (151), Ukrainians 1 percent (72), and Tatars 1 percent (48). The Soviet state has gradually blocked the Evenkis' access to their traditional sources of subsistence and stripped them of their language and right to self-government (Bloch 2004; Kozlov et al. 2007). A minority in their homelands, the Evenkis have become marginalized from decision-making processes that concern local natural resources, communal politics, and exercising their parental right to raise their children (Fondahl 1998). 
Together with the social and economic transformation of indigenous lifestyles, from the 1920s on, the Soviet authorities expended considerable energy on the cultural transformation of the Evenkis and their indigenous neighbors. Stalin viewed the Soviet community as the amalgamation of the best features of Soviet nations; since the share of Russian people in the formation of the Soviet community was so great, Stalin equated the Soviet and Russian cultures (Vdovin 2004). Consequently, the mass media represented Russian/Soviet culture as the most international, advanced, and humane, and one that would enrich the cultures of other nations. By the end of the 1930s, the new country received a visual outline of the attitude toward the country's history, its teaching, and the transformative role of the Russian people in the country and around the world (Vdovin 2004). Aiming at building a new nation and promoting patriotism among its new citizens, it was viewed as crucial to lifting the Evenkis and the other Siberian indigenous populations to the cultural and intellectual level of ethnic Russians. Thus, the Soviet civilizing mission was based on a rigid ethnic hierarchy that portrayed the Russians far above the indigenous peoples on the evolutionary ladder. The former had an obligation to guide the indigenous populations toward a socialist civilization, the pinnacle of human evolution. Accordingly, the decreasing influence and eradication of shamans and wealthy reindeer herders, the loss of subsistence activities, social disorganization, and ruptured family ties went hand-in-hand with the forced collectivization, industrialization, the formation of new professional structure, and the introduction of new compulsory residential schooling (Fondahl 1998).

The building of the new Soviet nation was accompanied by a growing awareness of a need for a common history and culture. First, the Soviet Union began to promote the concept of the country's progressive position in all the key areas of science, technology, and culture. The Russian people were represented as occupying a prominent place in the world culture. Accordingly, they were portrayed as the ones who contributed to the development of world sciences and made outstanding scientific discoveries, which represented the most important milestones in the development of modern culture and civilization. Second, the Soviet Union began promoting heroic and patriotic education (Vdovin 2004). The better execution of the nation-building goals was possible through a common educational system of citizens, including indigenous populations (Bartels and Bartels 1995). Thus, as in the rest of Siberia, education played a central role in the Soviet campaign 
of cultural transformation in Severobaikal'skii district, where the first residential school was established in 1925 (Shubin 2001: 83).

\section{Museums as Ideological Spaces}

Communist leaders envisioned museums as a critical element in cultural conversion and education, aimed at integrating the Evenkis into Soviet society and rooting out their lifestyle (Hirsch 2005; Khazanov 2000). According to Brenda Trofanenko (2006: 49), a museum is a "place where public exhibitions and displays of objects are held to embody essential forms of evidence of history, culture, nature, science, and art." The access to such discourse is a crucial condition of power: the ability to dictate one's picture of events, tell a story that fits the existing ideology and the stereotypical models, and enact power through the manipulation of public opinion. Here, I focus on the role of discourse in the reproduction of power. I look at how the local museum exercised social power to legitimize social policies toward the Evenkis, "naturalize" the social order, and construct identities. I derive these perspectives from Tony Bennett's (2014: 66) conceptualizations of "transformative capacities of the truths." Bennett puts forward this view in the course of discussing the place of museums in circulating and producing models for new realities and then put them in the context of contemporary practices and processes through which particular forms of power take place. He emphasizes that the critical characteristic of museums is a clear division between the real world and its representation in the form of the exhibition (Bennett 2013). Furthermore, Trofanenko (2006: 49) underlines the museum as rather a "cultural invention," which serves certain purposes. I show here that the construction of the Evenkis and history by a local museum is an interplay of real, imaginary, and ideological. On the one hand, there are the real Evenki people that live in the community and with whom the Russians have interacted for several hundred years. On the other, there are the imagined Evenkis-a set of mental images and stereotypes only loosely based on the real Evenkis that live in the community (Huusko 2017). The observed museum takes the real peoples' names and bibliographies and imposes onto them a narrative that reifies the official view of history. Effectively, the museum builds identity as a result of the continuous play of history, culture, and power. Bhabha (2013) describes identity as means by which people connect to the real or to the imagined as they perceive their personal and 
social world. Sari Pietikäinen (2003), in her research on Sámi identity, similarly highlighted the power of representations to define peoples' lives, their rights, and positions in the society. Consequently, the museum represents a "powerful identity-defining machine" (Duncan 1991: 101) that has the power not only to represent the community, but also to define and rank people in this community, and explicitly state that some have a greater share than others in the development of the community. I look at museum exhibitions as visual and textual narrative- $\mathrm{a}$ form of representation and thus a construction-which links identity and representations. I examine the style, rhetoric, and meaning of texts of the museum's exhibitions to reveal the discursive strategies of reproduction, including representation, legitimation, denial, and support.

The reproduction of dominance often requires justification or legitimation. The justification of social policies involves two complementary strategies: the positive representation of the own group and the negative representation of the others (Van Dijk 1993). Such polarized strategies tend to focus on negative social and cultural differences, contrasting "us" and "them," emphasize help and empathy, and contribute to sustaining existing attitudes as well the formation of new negative attitudes. I analyze the museum's attempts to define the Evenkis and Evenki culture by contrasting "us" and "them" or Russian/Soviet and Evenki cultures, while also appealing to humanitarian norms and values in arguing its support for social policies. Philip Deloria (1998) introduced the differentiation between the external and internal others in his research on indigenous-settler identity politics in the United States. Later Bell (2014) centered her analysis of the internal and external others in the politics of authenticity. He asserted that while internal other served as "a cultural source for the development of European national cultures," "modernity's 'external' Other, the authentic Primitive, served as a foil for intracultural criticism" (Bell 2014: 31). The author wrote about existing non-European peoples as a hypothesized human (European) past; through this endeavor, she also revealed how some discourses position European peasantry as another example of the hypothesized past of humans (read here Europeans) (Bell 2014). The author pointed out that any attempt to define or essentialize a group is problematic in its reductionism. I focus on the local museum's representations of the Evenkis, local community, and the state, and contrast several unique others categorized as either external others (the Evenkis as primitive) or internal others (the Evenkis as Soviet/Russian citizens). 


\section{A Local Museum's Representations of the Evenkis' Nature}

The way Severobaikal'skii Museum of Local History defines the community and Evenkis emerges from its institutional practices, including the objectives of the museum, its exhibitions, the narratives, and display of objects. Most of the museum's collections consist of posters with photographs and written texts on them, models of everyday objects, and pieces of cloths from different historical periods, as well as Evenki traditional cloths and a limited number of artifacts. The centerpiece of the Evenki section of the museum is a "poster gallery," which showcases a narrative written by a former curator, without consultations or any active participation of the local Evenki community. A current curator changed the place of the collection according to the "logic" of historical development and added new photographs and souvenirs. By introducing this narrative in its collection, the museum makes this narrative visible. It represents an imaginative reconstruction of the past and scenes of life in which all parts of the story are interconnected and have relationships between past and current events. What is invisible is made visible in this narrative imaginary - the lives and feelings of the prehistoric Evenkis, a disappearing people who require salvation. The museum views itself as an educational system, which aims at creating the local history, raising the respect among children for the historical objects and heroic glory of Russia, thus broadening school students' and youth's horizons and increasing their knowledge in the fields of history, culture, and geography (Severobaikal'skii municipal district n.d.). Thereby the museum attempts to shape the knowledge of the society through the selection of its exhibitions and presentation of artifacts.

The naming choices of the exhibitions and halls demonstrates not only how the museum represents the community and defines and ranks people, but also how the museum's practices are influenced by state ideology. The exhibitions are organized based on the progressive nature of social development according to dominant Soviet ideologies. The "gallery narrative" starts with the "discovery" and mapping of the region of the contemporary Severobaikal'skii district through the establishment of the first winter hut and fortress by the Russian Cossacks-as if the region had not existed before. By establishing the first winter hut, the museum puts the region on the map and locates it on the Marxist historical scale of evolution. The history of Russian settlers is marked by the advancements in technology, military skills, railroads, housing, mining, and farming. The narrative progresses 


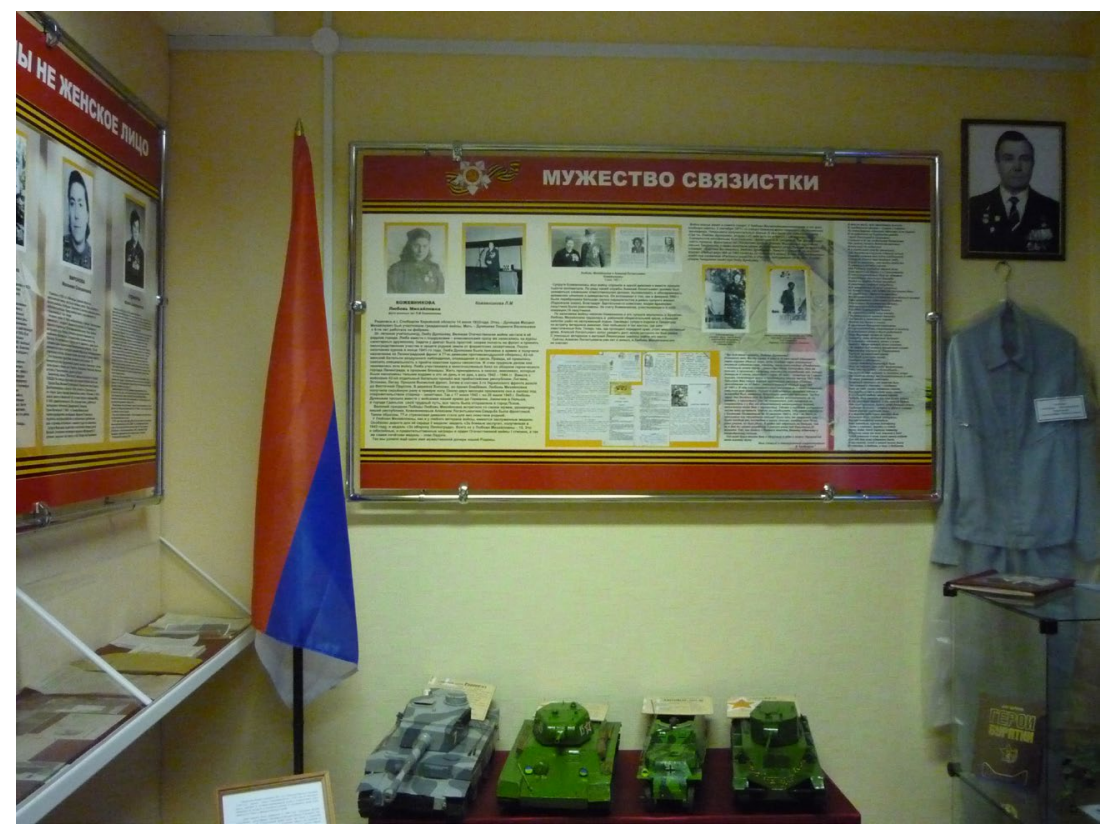

Figure 1. "Hall of Combat and Military Glory." Severobaikal'skii Museum of Local History, photograph by the author.

from those first winter huts through the material objects of Cossacks' housing during the Russian Empire, toward the Soviet narrative. At this point, there is no mention of the role of the indigenous people in the development of the region.

The museum's "Hall of Combat and Military Glory" celebrates the military glory of the Soviet Union and the heroism of Soviet people during World War II (Figures 1 and 2). The museum connects the history of the region and its people to the history and glory of the Soviet/ Russian state by highlighting their contribution to the victory and providing a list of the local World War II veterans.

The museum continues its storyline by underlining the continuity of the Soviet and contemporary Russian ideology. The continuity between the Soviet and Russian master narrative is represented through the contemporary photographs of local people, who hold portraits of their ancestors who died in World War II, during the annual Victory Day parades. Furthermore, the master narrative links the region to a larger nation-state through the logic of industrial and evolutionary progress. These industrialization efforts largely contributing to the ruination of Evenki ancestral homelands (Fondahl 1998; Reznikov and Adzhiev 2015; 


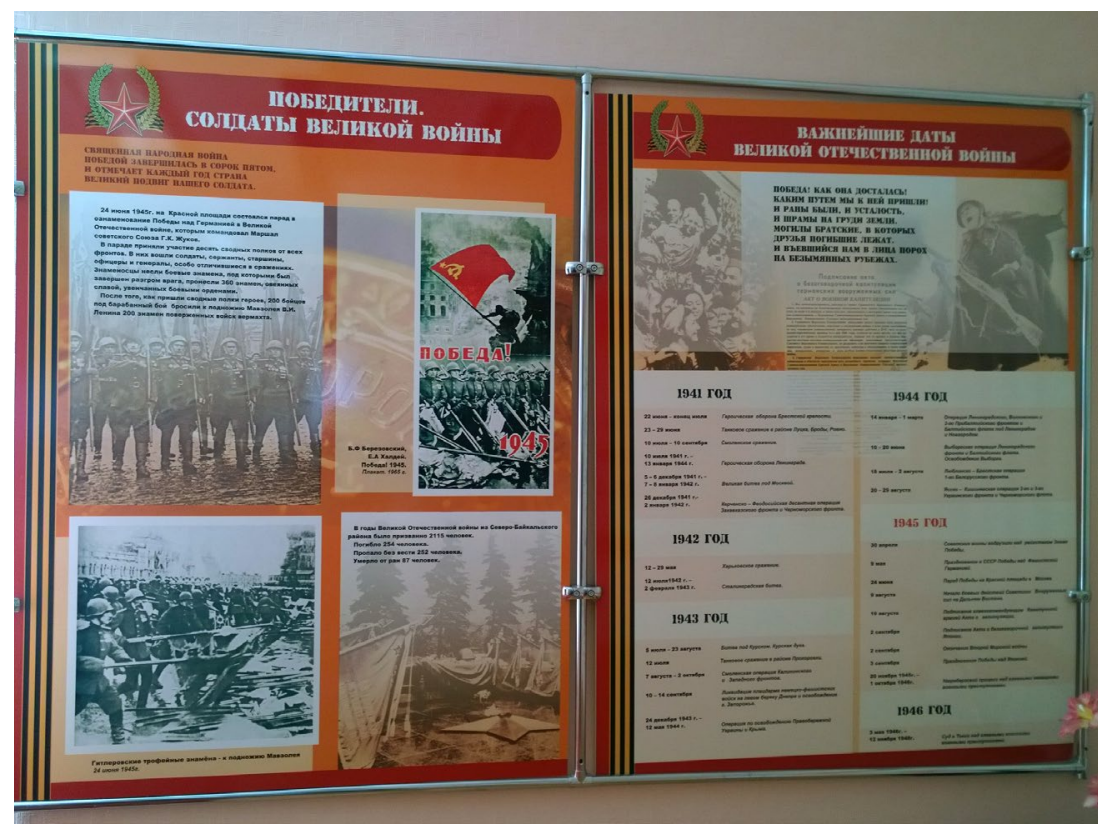

Figure 2. "The Winners, the Soldiers of the Great War." Severobaikal'skii Museum of Local History, photograph by the author.

Ziegler 1990), yet the exhibitions emphasize this discourse. "For half a century, the emphasis has been changing, but the main facts have remained constant: the importance of the construction of the Baikal-Amur Mainline railway for the economic development of Siberia and the Far East has never been denied. While its economic feasibility was implied, its military and strategic necessities were emphasized" (from a poster in Severobaikal'skii Museum of Local History in Nizhneangarsk).

According to the local Evenki residents, the construction of the Baikal-Amur Mainline railway forced the wild reindeer, whose meat was the primary source of food consumption among Evenkis, to leave the area. The land base used by the Evenkis decreased, and most of them had to abandon reindeer herding and other traditional livelihoods to work at the Baikal-Amur Mainline railway, various mining and construction sites, and collective state farms (Fondahl 1998). In Severobaikal'skii district, many Evenkis still have to work seasonally outside their home communities and rely on the state's social benefits for a part of the year.

Only at the end of the exhibition, there is an area that introduces the Evenkis as the indigenous people of the region. In this separate 
section, the rhetoric of progress and modernity moves from the relations between stages of production to the relations between races, nation, and ethnic groups. The Evenkis in this zone are presented as subject to civilizing forces. Reduced to displays of handicrafts and the posters explaining their "poor" living conditions, they are represented as a culture with no momentum and, thus, provide evidence for the necessity of the imperial power's mission of "improvement." In this section, the organizing principles for the construction of the museum's narrative are based on such discourses as "modernity," "primitiveness," and "nationhood." Russian and Soviet society is portrayed as being in control of science and industries, providing equal opportunities for men and women, and alone possessing the ability to manage and move forward into the future, while the Evenkis and the Evenki culture are portrayed as their primitive opposition.

The museum's discursive construction of the Evenki as "primitive other" is created through various European cultural and Soviet ideological lenses. Such perspectives as religion, subsistence, lifestyles, and technology defined and distorted the ways the ethnic Russians viewed the Evenkis. The museum ridicules the Evenki way of living before the Revolution: "the Natives lived the most pauper and miserable life, had no idea of bathing, medicine, or school, etc." (from a poster in Severobaikal'skii Museum of Local History in Nizhneangarsk).

The showcase of differences does not end here. Figure 3 demonstrates the museum's explanation of the animistic and polytheistic view of Nature by presenting the Evenkis' "primitiveness" as opposed to contemporary scientific explanations: "Not understanding the essence of natural phenomena, the elderly Evenkis explain them with religious positions, passing the tradition from generation to generation" (From a poster in Severobaikal'skii Museum of Local History in Nizhneangarsk). By doing this, the museum effectively constructs an image of an Evenki as a primitive creature driven by naive beliefs and the forces of nature. The museum also portrays the Evenkis as dying out and thus requiring rescues. Another poster states the following: "Befallen by epidemics of smallpox in 1883, the Chebkaanskii clan became almost completely extinct, and 70 percent of Kindigirskii clan had died. Only ten people of Chebkaanskii clan were left. In 1891, more than 60 percent of the population of the Shemagirskii clan died. The Tungus population was then nearly pushed to extinction by the typhus epidemic in 1916" (From a poster in Severobaikal'skii Museum of Local History in Nizhneangarsk).

In neutral terms - without providing any numerical or comparative data-the museum display shows that the Evenkis were already losing 


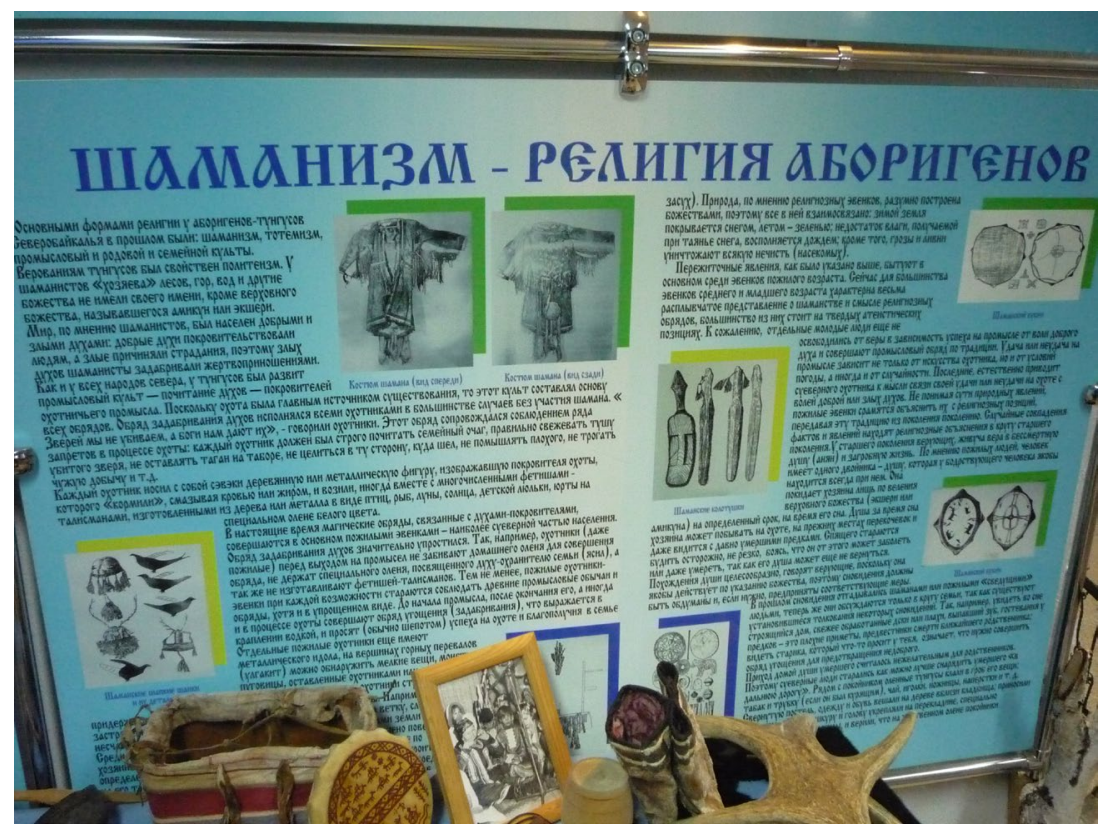

Figure 3. "Shamanism—the religion of the aborigines." Severobaikal'skii Museum of Local History, photograph by the author.

their lifestyle "long before the revolution," "Long before the revolution, Evenkis, who had lost their reindeer herds, had to either completely or partially cease their nomadic way of life, and settle on the banks of rivers and lakes, to become fishers" (from a poster in Severobaikal'skii Museum of Local History in Nizhneangarsk). Although some researchers have argued that the Evenkis were introduced to diseases through contact with Russian settlers (Fondahl 1998; Forsyth 1992; Landers 2011), the museum instead presents the negative developments as "natural" processes by using neutral words and phrases (e.g., the passive "had lost" in regard to their reindeer herds). According to the museum's information, the Tungus population had become extinct by 1916. Hence, taken together with the museum's essentialist view of the Evenki culture, by providing partial and sometimes distorted information, the museum produces new "evidence" for Evenkis dying out. There was thus no surprise when during my fieldwork, many local ethnic Russian people told me that there were no real Evenkis left in their district. This passage justifies the Soviet policies toward Indigenous peoples. If we paraphrase this statement, the museum asserts that even without the Soviet settlement policies, the Evenkis were naturally moving from 
nomadism toward the settled way of life. However, it does not provide the whole picture. Thus, Shubin (2001) writes that in the contemporary territory of Severobaikal'skii district by 1917 most of the Evenkis were engaged in commercial hunting as a subsistence type, which was in direct dependency with reindeer herding.

Although the Evenkis are still alive-and, furthermore, striving for cultural revitalization-this example shows how partial information is often presented by museums as truth to serve the dominant discourses. Moreover, it also demonstrates how the representation of these events is constructed as a natural sequence of events. By asserting that prior to the Soviet state the Evenkis were already losing control over their lives, good health, lifestyles, food supply, and safety from enemies (including traders), the museum's narrative justifies the need for the rescuing, civilizing and developing mission which was then employed by the Soviet state. Thus, the museum celebrates and welcomes the changes brought about by the introduction of residential schooling and Soviet development more broadly: "The Soviet state has created all the conditions for the cultural development of the small-numbered peoples of the Far North. In particular, residential schools were open for children of Nomads, in which [residential schools] children are kept on full state support. These residential schools existed in Dushkachan and Nizhneangarsk" (from a poster in Severobaikal'skii Museum of Local History in Nizhneangarsk). The museum thus creates tension between national and ethnic identities by ridiculing the Evenki ways of living before the advent of the Soviet state. It presents the prerevolution Evenkis as primitive, dying out external others (Bell 2014), separated from modern development.

The museum presents an effective exchange between visual and verbal discourse to convey different ideological positions. It includes visual, material, and written exhibits of the Evenki culture and objects used in ritual, reindeer herding, and hunting. Most of these objects are made by local artisans and represent the history of the Evenkis through their material culture and their relationship to the land and reindeer herding. The museum, however, stresses that the reindeer herding does not any longer constitute the main economic activity of the Evenkis, and portrays it as "remnant phenomena" (from a poster in Severobaikal'skii Museum of Local History in Nizhneangarsk). The museum effectively employs a strategy based on the rhetoric of difference-primitiveness as compared to the contemporary society, presenting an effective opposition to the glory of the state through the "miserable" and "poor" lives of the Evenkis prior to the revolution. This interplay between "primitive" 


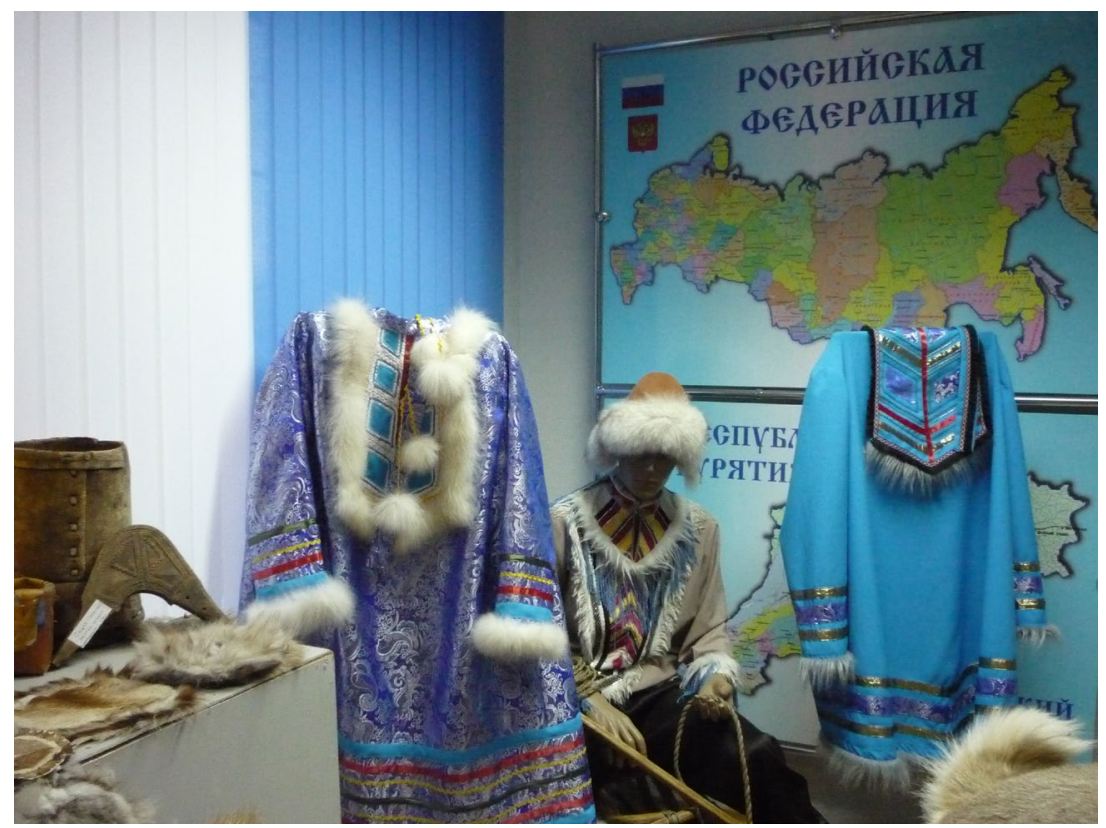

Figure 4. Incorporation of the Evenkis in Russian Space. Severobaikal'skii Museum of Local History, photograph by the author.

and "contemporary" becomes a defining characteristic of "tradition" and "modernity" in the museum.

However, the representations of the postrevolution Evenkis are changing. At this point, the museum starts constructing appropriate identities for the state. Aimed at constructing a new boundary of Russian national identity, the master narrative commences transferring the Evenkis as "external primitive other" into symbolic figures that could be rhetorically internal to the Russian nation and its modern society. A visitor can see how the museum starts to connect indigenous history and space to the contemporary state by situating Evenki space in relation to Russia, both geographically and politically (Figure 4).

The museum creates its representation of the Evenkis at the intersections of internal and external Evenkis and real and imagined Evenkis. As shown above, religion, lifestyle, and technology are often the criteria on which the opposition between contemporary society and primitive are built. These the same criteria are now used by the museum to build a case that demonstrates the benefits of belonging to the state. The museum (see Figure 3) points at the success of the state's civilizing mission by pointing at the disappearance of the primitive 
beliefs: "Shamanism — the religion of aborigines ... The remnant phenomena ... are prevalent mostly among the elderly Evenkis. Nowadays, middle-aged and young Evenkis have a rather vague idea of shamanism and religious rites" (from a poster in Severobaikal'skii Museum of Local History in Nizhneangarsk).

The museum continues constructing Evenkiness by juxtaposing the Evenki "traditional" lifestyle and technological benefits of contemporary society. In reality, the forced character of settlement, the relocation of the Evenkis, and the confiscation of their reindeer livestock led to the loss of subsistence activities, dispossession of indigenous hunting grounds, increased social disorganization, ruptured family ties, and the introduction of new professional structures wherein most of the Evenkis in the Severo-Baikalskii district had to take lower wage positions, or remain unemployed (Fondahl 1998; Shubin 2001). The museum, however, provides a "natural" picture of moving from nomadic to sedentary life. Claiming the antimodernity of "unsettled nomadic life," it celebrates new changes: "New times brought new customs. Evenki herders and hunters have long abandoned an unsettled nomadic life. Their families live now in proper modern settlements.... Many achievements of modern culture took up a firm position in Evenki hunters and reindeer herders' daily use ... . In their homes, there are radios, electric irons, and washing machines" (from a poster in Severobaikal'skii Museum of Local History in Nizhneangarsk).

The exhibition continues with justifying the changes that brought not only the modern conveniences but also varied diet: "Significant changes have occurred in the diet of the Evenkis. Before the basis of the diet consisted of meat and fish of all kinds.... A daily diet of an adult included half of a circle of fat [melted tarbagan, marmot fat] and two tablespoons of dried meat powder. With the development of trade relations in the second half of the nineteenth century, new products began to enter the Evenki life: tea, sugar, flour, butter and vegetable oil" (from a poster in Severobaikal'skii Museum of Local History in Nizhneangarsk).

While the museum attempts to praise the Evenkis' attitude toward their culture by stating that "the Evenki people cherish their national particularities," it also affirms that "a departure from Evenki traditions started a few decades ago." The museum not only builds the understanding of modernity by comparing between the "primitive" Evenki forms of being and contemporary Soviet/Russian society but also justifies and celebrates the dominant ideology in its forms of discourse.

Consequently, the museum moves gradually toward incorporating the Evenkis and their lifestyle into the Soviet lifestyle by highlighting 
the purposes of the state, such as patriotic themes, active citizenship, and hard work that fulfills the needs of the state. Thus, the museum constructs the Evenkis as not the external primitive others, but as Soviet people, who are in full contact with Soviet society and are active, hardworking citizens. A few such examples are below:

Maria Petrovna Uronchina is an amazing woman ... a communist and the oldest farmer of the Collective farm "Friendship" of the Council of Kindigir Village [the primary authority of the Soviet government in the rural areas] ... For a long time, she has been a hunter ... a reindeer herder, the head of the collective farm during World War II . . . Maria Petrovna Uronchina is a great connoisseur of the Evenki folklore and a famous narrator. ... The Presidium of the Council of the [Buriat] Republic awarded her the title of Honored Worker of Culture of the Buriat Republic.

Vasilii Dokolev participated in the World War II, ... studied at the Institute of People of the North. His father was one of the first chairmen of the Evenki rural Soviets [the primary authority of the Soviet government in the rural areas]. Vasilii Dokolev was the editor of the local newspaper ... worked in party work for 35 years.

Tatiana Iakovlevna Tulbukonova is a hunter and a reindeer herder. At the same time, she was guarding reindeer herds of the collective farm. The Communist Party and the government highly appreciated the work of the ordinary farmer of the Collective farm.

(From posters in Severobaikal'skii Museum of Local History in Nizhneangarsk)

Thereby, the museum creates an opposition between the external prerevolution Evenkis and internal Evenkis as citizens of the state. It constructs the internal Soviet/Russian citizen, an Evenki, who is still an other with a distinguishable look and culture, but this time the internal other, a modern Evenki who legitimates a broader national identity. By connecting the history of the region to the history of the state, the museum offers its visitors a choice to identify themselves by effectively providing identity-building material, which is based on the opposition of modernity and tradition-self-belonging and pride in the glory of the strong, modern state, as opposed to a dying-out indigenous lifestyle. For the museum, it is a showcase of the benefits of explaining traditional pasts through modern ideological concerns.

The motherland, the history, and the heroes are all reconsidered and connected to the larger nation-state. They do not exist outside the state history; they are the heroes of everyday Soviet working life 
or fighters in World War II. The museum effectively incorporates the patriotic themes with Evenkis incorporated inside of Russian history. It emphasizes the role of the state in the cultural development of the Evenkis from being "primitive" to becoming sedentarized, and then finally as citizens of "modern" and "strong" state. The museum's narrative effectively internalizes the "external primitive other" - the Evenkis outside the Soviet history and state-into the "internal other," with the Evenkis as Soviet/Russian citizens in possession of a distinct culture but a common purpose in line with Russian national interests.

The museum constructs a causally oriented narrative of the sequence of the events into an intelligible pattern offered to the museum's visitors. This causality provides "naturalness" to this representation of events. This representation of history, events, the region, and the people offers not only the justification of the events but also the necessity of them through the construction of this causality in which the events are linked together. By this construction, the museum attempts to shape human values by explaining traditional pasts while referencing modern ideological concerns. The museum reinforces the dominant vocabularies, which in turn promote stereotypes that deprive indigenous people of their own history and culture. It becomes evident that the local museum has evolved into the institution of power and represented the system of knowledge which is, in turn, the reflection of governmental politics and ideology. The museum adopts Soviet political discourse which, in turn, produces opposition between science and faith, and a tension between national and ethnic identities. These tensions shape a local field of debate about the Evenkis, their tradition, and their place in the history of the region. The museum borrows the Soviet ideas and practices relating to religion, culture, primitivity and national identity, thereby eliminating any possibilities of exploring contemporary Evenki identity and traditions narrated by Evenkis themselves.

The reproduction of dominance has two major aspects: the direct enactment of dominance and its consequences in the process of management of public opinion. School students come to the museum on field trips. They all have different backgrounds, and their interpretations of the exposition could lead to different outcomes, including the development of prejudice and stereotypes. For the Evenki youth, the museum's textual and visual narrative becomes a showcase of their culture, locked in the past. It also presents a choice: do they want to be part of modern and advanced society, or stay in the past? However, this choice is again invented by the dominant society, by purposefully depicting the Evenki 
community as outdated and backward. Consequently, it could lead to the image of the "native" they want to negotiate or avoid (Huusko 2017).

The museum has written an "autobiography" of the region and the people that live in that region. However, for the Evenkis, it is a biography that is written about them, rather than an autobiography. Further research into this space could be done by looking at how Evenki collective memories and individual stories highlight changing Evenki traditions, political regimes, and their own identities as dynamic processes. During my fieldwork, I noticed that different people hold different memories of boarding schools. It would be interesting to explore how these memories intervene and conflict in the process of articulating the narrative. Another valuable perspective would be to look at the process of writing the narrative itself. Several attempts of creating an Evenki museum have already been made by a local school, by one of the Evenki villages, and by the Children's Cultural Centre. However, they have not yet come to a consensus and to the point of negotiating their attempts.

\section{Acknowledgments}

The fieldwork conducted for this article in 2016 was financially supported by Öflunds Stiftelse sr.

Svetlana Huusko is a PhD student at the Cultural Anthropology at the University of Oulu. She is an indigenous Buriat person from Buriatiia. Her research focuses on how the indigenous Evenki adolescents negotiate their identity in the context of competing representations of Evenkiness and indigeneity in Buriatiia in contemporary Russia. Email: svetlanaahuusko@gmail.com.

\section{Note}

1. According to the Russian federal legislation, indigenous peoples are "peoples living in the territories of the North, Siberia and the Far East in the territories of traditional settlement of their ancestors, preserving a traditional way of life and a traditional economic system and economic activities, numbering fewer than 50,000 persons, and recognizing themselves as independent ethnic communities" (Russian Fedeartion 2000). 


\section{References}

Bartels, Dennis, and Alice Bartels. 1995. When the North Was Red: Aboriginal Education in Soviet Siberia. Montreal: McGill-Queen's University Press.

Bashkuev, Vsevolod. 2013. "Silencing the Shame: Forgetting of the 1920s Syphilis Epidemic in Buryat-Mongolia as a Strategy of Post-Soviet Identity Construction." Jefferson Journal of Science and Culture 3: 110-32.

Bell, Avril. 2014. Relating Indigenous and Settler Identities: Beyond Domination. Basingstoke, Hampshire: Palgrave Macmillan.

Bennett, Tony. 2013. The Birth of the Museum: History, Theory, Politics. Oxon: Routledge.

Bennett, Tony. 2014. "Museums, Nations, Empires, Religions." In National Museums and Nation-Building in Europe, 1750-2010: Mobilization and Legitimacy, Continuity and Change, ed. Peter Aronsson and Gabriella Elgenius, 66-86. Oxon: Routledge.

Bhabha, Homi K. 2013. Nation and Narration. New York: Routledge.

Bisher, J. 2006. White Terror: Cossack warlords of the Trans-Siberian. London: Routledge.

Bloch, Alexia. 2004. Red Ties and Residential Schools: Indigenous Siberians in a Post-Soviet State. Philadelphia: University of Pennsylvania Press.

Deloria, Philip Joseph. 1998. Playing Indian. New Haven: Yale University Press.

Duncan, Carol. 1991. "Art Museums and the Ritual of Citizenship." In Exhibiting Cultures: The Poetics and Politics of Museum Display, ed. Ivan Karp and Steven D. Lavine, 88-103. Washington, DC: Smithsonian Institution Press.

Fondahl, Gail. 1998. Gaining Ground? Evenkis, Land and Reform in Southeastern Siberia. Boston: Allyn and Bacon.

Forsyth, James. 1992. A History of the Peoples of Siberia: Russia's North Asian Colony, 1581-1990. Cambridge: Cambridge University Press.

Gandy, Daniel Ross. 2012. Marx and History: From Primitive Society to the Communist Future. Austin: University of Texas Press.

Grant, Bruce. 1993. "Siberia Hot and Cold: Reconstructing the Image of Siberian Indigenous Peoples." In Between Heaven and Hell: The Myth of Siberia in Russian Culture, ed. Galya Diment and Yuri Slezkine, 227-54. New York: St. Martin's Press.

Hamayon, Roberte N. 2002. "Emblem of Minority, Substitute for Sovereignty: The Case of Buryatia." Diogenes 49 (194): 16-21.

Hirsch, Francine. 2005. Empire of Nations: Ethnographic Knowledge and the Making of the Soviet Union. Ithaca: Cornell University Press.

Huusko, Svetlana. 2017. "Local Representations of Evenkiness and Managing Identities among Evenki Adolescents in Buryatia." Inner Asia 19 (2): 274-96. doi: https://doi.org/10.1163/22105018-12340091

Khazanov, Anatoly M. 2000. "Selecting the Past: The Politics of Memory in Moscow's History Museums." City E Society 12 (2): 35-62. doi:10.1525/ city.2000.12.2.35. 
Kozlov, Andrew, Galina Vershubsky, and Maria Kozlova. 2007. Indigenous Peoples of Northern Russia: Anthropology and Health. Raahe, Finland: International Association of Circumpolar Health.

Landers, Brian. 2011. Empires Apart: A History of American and Russian imperialism. New York: Pegasus Books.

Lee, Jaehoon. 2013. "Indigenous People and Political Agenda: The Issue of Social and Ecological Change of the Nomadic Siberian, the Evenki, in Russia." Journal of Contemporary Anthropology 4 (1): Article 1. https://docs. lib.purdue.edu/jca/vol4/iss1/1.

Leete, Art. 2005. "Religious Revival as Reaction to the Hegemonization of Power in Siberia in the 1920s to 1940s." Asian Folklore Studies 64 (2): 233-45.

Pietikäinen, Sari. 2003. "Indigenous Identity in Print: Representations of the Sami in News Discourse." Discourse \& Society 14 (5): 581-609.

Reznikov, S. A., and R. A. Adzhiev. 2015. "Persistent Organic Pollutants in Bottom Sediments in the North of Lake Baikal in the Area of the BaikalAmur Mainline Impact." Meteorologiia i Gidrologiia 40 (3): 207-14. doi: https://doi.org/10.3103/S1068373915030085.

Russian Census. 2010. Respublika Buriatiia: Osnovnye itogi vserossiiskoi perepisi naseleniia 2010 goda. http://burstat.gks.ru/wps/wcm/connect/rosstat_ts/ burstat/ru/census_and_researching/census/national_census_2010/ score_2010/ (accessed 31 August 2017).

Russian Federation. 2000. Federal Law on General Principles for Organization of Communes of Indigenous Peoples of the North, Siberia and the Far East of the Russian Federation of 20 July 2000, No. 104-FZ. http://base.garant. $\mathrm{ru} / 182356 /$.

Severobaikal'skii Municipal District. n.d. http://sb-rayon.ru/o-rajone/istoriyarajona.html.

Shubin, Aleksandr S. 2001. Evenki Pribaikal'a. Ulan-Ude: Belig.

Slezkine, Yuri. 1994. Arctic Mirrors: Russia and the Small Peoples of the North. Ithaca: Cornell University Press.

Ssorin-Chaikov, Nikolai. 2001. "Evenki Shamanistic Practices in Soviet Present and Ethnographic Present Perfect." Anthropology of Consciousness 12 (1): 1-18. doi:10.1525/ac.2001.12.1.1

Trofanenko, B. 2006. "Interrupting the Gaze: On Reconsidering Authority in the Museum." Journal of Curriculum Studies 38 (1): 49-65.

Ulturgasheva, Olga. 2012. Narrating the Future in Siberia: Childhood, Adolescence and Autobiography among the Eveny. New York: Berghahn Books.

USSR Census. 1926. Vsesoiuznaia perepis' naseleniia 1926 goda. RSFSR i ee regiony. Naselennye mesta. Nalichnoe gorodskoe i sel'skoe naselenie. http://demoscope.ru/ weekly/ssp/rus_26.php?reg=444.

USSR Census. 1989. Vsesoiuznaia perepis' naseleniia 1989 goda. Chislennost' naseleniia SSSR, RSFSR i ee territorial'nykh edinits po polu. http://demoscope.ru/weekly/ ssp/rus89_reg1.php. 
Van Dijk, Teun A. 1993. "Principles of Critical Discourse Analysis." Discourse E Society 4 (2): 249-83. doi: https://doi.org/10.1177/0957926593004002006.

Vasilevich, Glaphira M., and Smolyak Anna V. 1964. "The Evenks.” In The Peoples of Siberia, ed. M. G. Levin and L. P. Potapov, 620-54. Chicago: University of Chicago Press.

Vdovin, Aleksandr. 2004. Russkie v XX veke. Moscow: Olma Press.

Ziegler, Charles E. 1990. Environmental Policy in the USSR. Amherst: University of Massachusetts Press. 